\author{
В.В. Канищев, А.С. Морозов, В.П. Лакомов, Ю.В. Омельяненко, \\ С.Р. Бухаева, Р.Г. Трошев, А.Г. Муравьев
}

Филиал федерального государственного бюджетного учреждения
«8 Центральный научн-исследовательский институт"
Министерства обороны Российской Федерации (2. Екатеринбург),
620085, Российская Федерация, г. Екатеринбург, ул. Звездная, д. 1

Поступила 25.05.2018 г. Принята к публикации 15.10.2018 г.

Проведение дезинфекционных мероприятий в случае возникновения эпидемических очагов искусственного или естественного происхождения сопряжено с большим расходом дезинфицирующих средств, особенно в очагах сибирской язвы, и не исключает ситуации, когда запаса табельных дезинфицирующих средств может оказаться недостаточно и потребуется использование нетабельных дезинфицирующих средств. Цель работы - выявить среди зарегистрированных в России дезинфицирующих средств наиболее пригодные для использования войсками РХБ защиты в чрезвычайных ситуациях биологического характера. Всего было проанализировано 770 наименований таких средств. Установлено, что в практику российских медицинских учреждений уже почти два десятилетия внедряются дезинфицирующие средства группы катионных поверхностно-активных веществ (КПАВ) на основе четвертичных аммониевых соединений, аминов, полигуанидинов и композиций этих действующих веществ в различном сочетании. Анализ данных научной литературы и результатов собственных экспериментов показал, что спороцидного эффекта растворы этих дезинфицирующих средств, рекомендуемые для стерилизации и дезинфекции высокого уровня изделий медицинского назначения, не оказывают. Поэтому интерес в качестве нетабельных дезинфицирующих средств для войск РХБ защиты могут представлять лишь дезинфицирующие средства на основе хлорсодержащих и кислородсодержащих действующих веществ. Растворы таких средств имеют широкий спектр антимикробного действия и обеспечивают полную гибель на объектах не только бактерий, вирусов и грибов, но и спор различных бацилл, в том числе и при температурах ниже $0^{\circ} \mathrm{C}$. Наиболее пригодными из них для использования войсками РХБ защиты являются средства в виде быстрорастворимых таблеток на основе натриевой соли дихлоризоциануровой кислоты, а также в виде жидких концентратов на основе перекиси водорода или надуксусной кислоты. Поэтому в чрезвычайных ситуациях биологического характера вышеуказанные средства должны применяться войсками РХБ защиты по режимам табельного средства на основе аналогичного действующего вещества.

Ключевые слова: дезинфекиия; дихлоризоциануровая кислота; надуксусная кислота; очаг биологического заражения; перекись водорода; сибирская язва; спороцидный дезинфицирующий агент; табельное дезинфииирующее средство; техническое средство специальной обработки; четвертичное аммониевое соединение; чрезвычайная эпидемическая ситуачия.

Библиографическое описание: Канищев В.В., Морозов А.С., Лакомов В.П., Омельяненко Ю.В., Бухаева С.Р., Трошев Р.Г., Муравьев А.Г. Использование зарегистрированных в России дезинфицирующих средств войсками РХБ защиты в чрезвычайных ситуациях биологического характера // Вестник войск РХБ защиты. 2018. Т. 2. № 3. С. 57-67. 
В.В. Канищев, А.С. Морозов, В.П. Лакомов и др.

Таблица 1 - Сравнительная оценка дезинфектантов различных классов по основным показателям

\begin{tabular}{|c|c|c|c|c|c|c|c|}
\hline \multirow{3}{*}{$\begin{array}{c}\text { Дезинфициру- } \\
\text { ющие } \\
\text { средства }\end{array}$} & \multicolumn{7}{|c|}{ Степень выраженности некоторых целевых свойств } \\
\hline & \multicolumn{2}{|c|}{ Спороцидная активность } & \multirow[b]{2}{*}{$\begin{array}{c}\text { Токсич- } \\
\text { ность для } \\
\text { людей }\end{array}$} & \multirow{2}{*}{$\begin{array}{c}\text { Совмести- } \\
\text { мость с } \\
\text { органи- } \\
\text { ческими } \\
\text { антифри- } \\
\text { зами }\end{array}$} & \multirow{2}{*}{$\begin{array}{c}\text { Полифунк- } \\
\text { циональ- } \\
\text { ность } \\
\text { (дезинфек- } \\
\text { ция и дега- } \\
\text { зация) }\end{array}$} & \multirow[b]{2}{*}{$\begin{array}{l}\text { Коррози- } \\
\text { онная ак- } \\
\text { тивность }\end{array}$} & \multirow{2}{*}{$\begin{array}{c}\text { Примени- } \\
\text { мость из } \\
\text { штатных } \\
\text { техни- } \\
\text { ческих } \\
\text { средств }\end{array}$} \\
\hline & $\begin{array}{c}\text { при положи- } \\
\text { тельных тем- } \\
\text { пературах }\end{array}$ & $\begin{array}{c}\text { при отрица- } \\
\text { тельных тем- } \\
\text { пературах }\end{array}$ & & & & & \\
\hline $\begin{array}{c}\text { Препараты } \\
\text { гипохлорита Сa } \\
\text { и Na }\end{array}$ & $++1)$ & $+1)$ & $+++1)$ & - & $\begin{array}{c}\text { Обеспечи- } \\
\text { вают }\end{array}$ & +++ & $\begin{array}{c}\text { Обеспечи- } \\
\text { вают }\end{array}$ \\
\hline $\begin{array}{c}\text { Препараты на } \\
\text { основе дихлор } \\
\text { или трихлори- } \\
\text { зоциануровой } \\
\text { кислоты } \\
\end{array}$ & ++ & + & ++ & + & $\begin{array}{c}\text { Обеспечи- } \\
\text { вают }\end{array}$ & ++ & $\begin{array}{c}\text { Обеспечи- } \\
\text { вают }\end{array}$ \\
\hline $\begin{array}{c}\text { Неорганические } \\
\text { кислоты }\end{array}$ & ++ & $-2)$ & +++ & - & - & +++ & - \\
\hline Щелочи & + & - & ++ & - & $\begin{array}{c}\text { Обеспечи- } \\
\text { вают }\end{array}$ & ++ & $\begin{array}{c}\text { Обеспечи- } \\
\text { вают }\end{array}$ \\
\hline $\begin{array}{l}\text { Перекись } \\
\text { водорода }\end{array}$ & ++ & + & + & +++ & $\begin{array}{c}\text { Обеспечи- } \\
\text { вают }\end{array}$ & ++ & Не из всех \\
\hline $\begin{array}{c}\text { Композиции } \\
\text { перекиси водо- } \\
\text { рода с низкомо- } \\
\text { лекулярными } \\
\text { органическими } \\
\text { кислотами } \\
\end{array}$ & +++ & ++ & + & +++ & $\begin{array}{c}\text { Обеспечи- } \\
\text { вают }\end{array}$ & ++ & Не из всех \\
\hline Альдегиды & + & - & +++ & +++ & $\begin{array}{c}\text { Обеспечи- } \\
\text { вают }\end{array}$ & + & $\begin{array}{c}\text { Обеспечи- } \\
\text { вают }\end{array}$ \\
\hline Спирты & - & - & + & +++ & $\begin{array}{c}\text { Обеспечи- } \\
\text { вают }\end{array}$ & - & $\begin{array}{c}\text { Обеспечи- } \\
\text { вают }\end{array}$ \\
\hline ЧAC & - & - & + & +++ & - & - & $\begin{array}{l}\text { Обеспечи- } \\
\text { вают }\end{array}$ \\
\hline $\begin{array}{l}\text { Примечание: } \\
\text { 1) }(+++) \text { - очень } \\
\text { 2) - сведения о }\end{array}$ & ; $(++)$ & 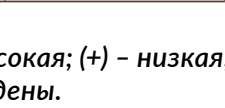 & & & & & \\
\hline
\end{tabular}

При проведении войсками РХБ защиты дезинфекционных мероприятий в очагах биологического заражения (ОБ3) или при других чрезвычайных эпидемических ситуациях имеющегося запаса табельных дезинфицирующих средств может оказаться недостаточно. Например, ликвидация очагов сибирской язвы сопряжена с необходимостью применения высококонцентрированных (спороцидных) рабочих растворов дезинфицирующих средств и большим их расходом на единицу поверхности обрабатываемого объекта. К тому же, не всегда можно заранее оценить масштаб биологического заражения $[1,2]$.

Цель работы - выявить среди зарегистрированных в России дезинфицирующих средств наиболее пригодные для использования войсками РХБ защиты в чрезвычайных ситуациях биологического характера

Дезинфицирующее средство для специальной обработки должно удовлетворять требованиям, обусловленным спецификой их использования войсками РХБ защиты и возможными условиями проведения дезинфекции различных объектов в эпидемических очагах искусственного или естественного происхождения. К таким обязательным требованиям относятся следующие [1]:

- широкий спектр антимикробного действия в отношении вегетативных и споровых форм микроорганизмов;

- возможность эффективного применения в условиях как положительных, так и отрицательных температур с использованием штатных технических средств специальной обработки;

- малая токсичность для людей и низкая коррозионная активность в отношении обрабатываемых объектов.

Экономические затраты, связанные с использованием нетабельных дезинфицирующих средств, являются важным аргументом при их выборе. Они должны, на наш взгляд, быть сопоставимы с затратами применения табельных средств.

В таблице 1 дана сравнительная оценка на соответствие указанным выше требованиям ос- 
Использование зарегистрированных в России дезинфицирующих средств войсками РХБЗ...

Таблица 2 - Динамика разработки и внедрения в отечественную практику дезинфицирующих средств

\begin{tabular}{|c|c|c|c|c|}
\hline \multirow{2}{*}{$\begin{array}{l}\text { Классификация } \\
\text { дезинфекционных } \\
\text { средств по действую- } \\
\text { щим веществам }\end{array}$} & \multirow{2}{*}{$\begin{array}{c}\text { Субстанции, использованные в средстве в } \\
\text { качестве действующих веществ }\end{array}$} & \multicolumn{3}{|c|}{$\begin{array}{c}\text { Количество дезинфекционных } \\
\text { средств по состоянию на декабрь ... }\end{array}$} \\
\hline & & 2001 г.* $^{*}$ & 2013 г.** $^{* *}$ & 2017 г.*** \\
\hline \multirow{6}{*}{ Хлорсодержащие } & Гипохлорит кальция & 16 & 3 & 4 \\
\hline & Гипохлорит натрия & 4 & 9 & 10 \\
\hline & Натриевая соль ДХЦК & 14 & 71 & 79 \\
\hline & Натриевая соль ТХЦК & 2 & 7 & 8 \\
\hline & Хлорамин & 4 & 3 & 3 \\
\hline & Дихлоргидантоин & 3 & 2 & 4 \\
\hline \multirow{5}{*}{ Кислородсодержащие } & Перекись водорода & 4 & 14 & 20 \\
\hline & $\begin{array}{c}\text { Перекись водорода + уксусная кислота } \\
\text { (надукс. к-та) }\end{array}$ & 6 & 23 & 34 \\
\hline & $\begin{array}{c}\text { Перекись водорода + муравьиная кислота } \\
\text { (надмур. к-та) }\end{array}$ & 0 & 1 & 1 \\
\hline & Перекись водорода + КПАВ (ЧАС или/и ПГМГХ) & 1 & 27 & 31 \\
\hline & Пербораты, персульфаты, перфториды & 8 & 5 & 15 \\
\hline \multirow{2}{*}{ Альдегидсодержащие } & $\begin{array}{c}\text { Альдегид (глутаровый, пента-фталевый, } \\
\text { формальдегид и др.) }\end{array}$ & 13 & 23 & 33 \\
\hline & Глутаровый альдегид +ЧАС & 15 & 74 & 86 \\
\hline \multirow{6}{*}{ Катионактивные ПАВ } & ЧAC & 40 & 154 & 164 \\
\hline & Полигуанидин (ПГМГХ) & 9 & 20 & 31 \\
\hline & Амин & 3 & 18 & 23 \\
\hline & ЧАС + полигуанидин & 11 & 70 & 82 \\
\hline & ЧАС + амин & 4 & 77 & 93 \\
\hline & ЧАС + амин + полигуанидин & 0 & 54 & 74 \\
\hline \multicolumn{2}{|r|}{ Всего дезсредств } & 158 & 654 & 772 \\
\hline \multicolumn{5}{|c|}{$\begin{array}{l}\text { * По состоянию на } 2001 \text { г. - на основе данных справочника «Дезинфекционные средства» [10]; } \\
\text { ** На } 2013 \text { г. - обзора Канищева В.В. и Еремеева Н.И. [11]; } \\
\text { *** На } 2017 \text { 2. - по информации, размещенной на сайте «ДЕЗРЕЕСТР» (Национальный справочно-аналитический } \\
\text { maл о дезсредствах, зарегистрированных на территории РФ (Оfficial information site on disinfectants). } \\
\text { : http://www.dezreestr.ru (дата обращения: 30.01.2018). }\end{array}$} \\
\hline
\end{tabular}

новных химических дезинфицирующих веществ с учетом научных данных об их свойствах [3-10].

Из приведенных в таблице 1 данных следует, что среди используемых в качестве действующих веществ известных субстанций нет таких, которые удовлетворяют полностью требованиям специальной обработки. Лишь по совокупности свойств и с учетом наличия спороцидной эффективности можно выделить хлорсодержащие вещества (растворы гипохлоритов, солей дихлор- и трихлоризоциануровой кислоты), а также перекись водорода и ее композиции с органическими кислотами. Другие действующие вещества или не обладают (например, четвертичные аммониевые соединения $[3,5,7])$, или обладают очень слабой спороцидной активностью (например, альдегиды) даже в условиях положительных температур $[1,5,9]$.

Общее представление о количестве разработанных за последнее десятилетие действующих веществ и их композиций дают данные таблицы 2.

Как видно из таблицы 2, рынок зарегистрированных для применения в медицинской практике дезинфицирующих средств за последние 16 лет увеличился почти в 5 раз. При этом наибольшими темпами разрабатывались и внедрялись в практику средства группы катионных поверхностно-активных веществ (КПАВ) на основе четвертичных аммониевых соединений, аминов, полигуанидинов и композиций этих действующих веществ в различном сочетании. Их количество увеличилось в 7 раз, так что сегодня они составляют почти $71 \%$ от общего количества зарегистрированных дезинфицирующих средств. И это неслучайное явление. Оно отражает тенденцию разработки и внедрения дезинфектантов, диктуемую их спросом и сферой потребления.

В частности, ежедневным потребителем большого объема дезинфицирующих средств стали различные лечебно-профилактические организации (ЛПО). Основной болезнетворной микрофлорой ЛПО, подлежащей уничтожению, являются вегетативные формы микроорганизмов, a объектами дезинфекции - дорогостоящие, чувствительные (в плане повреждения) к воздействию агрессивными жидкостями различные инструменты, приборы, оборудование и т.п. По- 
этому дезинфицирующие средства на основе КПАВ, отличающиеся низкой токсичностью и слабой коррозионной активностью $[5,7,8]$, стали интенсивно разрабатываться, производиться и внедряться в практику ЛПО многочисленными коммерческими фирмами. В инструкциях по их применению даны режимы для дезинфекции не только в отношении класса низкоустойчивых к дезинфицирующим средствам болезнетворных микроорганизмов, но и класса среднеустойчивых (типа микобактерий туберкулеза, полиовирусов и др.) и даже спор бацилл (более 50 средств) ${ }^{1}$.

Вместе с тем известно, что дезинфицирующие средства на основе КПАВ малоэффективны в отношении безоболочечных вирусов и микобактерий, вызывающих туберкулез [5, 7, 8]. А наличие у дезинфектантов на основе КПАВ, не содержащих других спороцидных действующих веществ, режимов стерилизации вступает в противоречие с научными данными о неэффективности дезинфектантов типа четвертичных аммониевых соединений (ЧАС), алкиламинов и гуанидинов в отношении спор бактерий $[3,5,7$, 8, 12-14]. В частности отмечается: «Не обладают спороцидной активностью средства на основе ЧАС, полимерных и мономерных производных гуанидина, третичных алкиламинов, спиртов, производных фенолов и композиционные составы на основе этих соединений, независимо от концентрации последних в рабочих растворах. Перечисленные средства нельзя применять ни для дезинфекции объектов, контаминированных бактериями в споровой форме, ни для стерилизации...» [3].

Это наглядно подтверждают результаты и нашей собственной экспериментальной оценки спороцидных свойств некоторых зарегистрированных в России субстанций и композиционных средств на основе КПАВ, приведенные в таблице 3. Они показывают, что никакого спороцидного эффекта за приемлемое для практики время рабочие растворы этих дезинфицирующих средств, рекомендуемые для стерилизации и дезинфекции высокого уровня изделий медицинского назначения, не оказывают. Порядка 60\% ДС этой группы имеют еще и заниженные в десятки (и более) раз бактерицидные концентрации рабочих растворов в угоду обеспечения им преимуществ перед аналогами $[11,16]$.

Рекомендации по применению дезинфицирующих средств с заниженными концентрациями рабочих растворов, к сожалению, получили широкое распространение. На это обращается внимание в информационном письме Научно-исследовательского института дезинфек- тологии Роспотребнадзора (ФБУН НИИДезинфектологии, Москва) о результатах экспертной оценки 78 наименований дезинфицирующих средств, зарегистрированных для применения в России, размещенном на официальном сайте института $^{2}$. Установлено, что «более чем в половине случаев рекомендуемые режимы применения дезинфицирующих средств предлагают заниженные концентрации и недостаточное время экспозиции»

Использовать дезинфицирующие средства с такими режимами для дезинфекции микроорганизмов 1 и 2 групп патогенности (а именно с ними будут иметь дело в чрезвычайных эпидемических ситуациях) - значит ставить под угрозу здоровье и жизнь людей.

В этой связи интерес для использования при ликвидации чрезвычайных ситуаций биологического характера войсками РХБ защиты в качестве нетабельных дезинфицирующих средств могут представлять лишь дезинфицирующие средства на основе хлорсодержащих и кислородсодержащих действующих веществ. Растворы таких средств имеют широкий спектр антимикробного действия и обеспечивают полную гибель на объектах не только бактерий, вирусов и грибов, но и спор различных бацилл, в том числе и при температурах ниже $0^{\circ} \mathrm{C}[2-4,7,17,18]$.

Поскольку режимы применения и этих потенциально спороцидных дезинфицирующих средств не отрабатывались с учетом возможности их использования войсками РХБ защиты в чрезвычайных ситуациях, то применяться для этих целей они, на наш взгляд, могут и должны не по инструкциям на них, а по режимам (концентрация и расход) применения табельных дезсредств. А это значит, что концентрация действующего вещества в них и рабочих растворах должна по крайней мере быть сопоставимой с таковой у табельных средств.

С целью объективного и обоснованного выбора пригодных (перспективных) для использования войсками РХБ защиты при ликвидации чрезвычайных эпидемических ситуаций необходимо провести анализ этих групп зарегистрированных дезинфицирующих средств.

Из трех зарегистрированных и производимых в России средств на основе гипохлорита кальция, только два средства удовлетворяют отмеченным ранее требованиям. Одним из них является «Двуосновная соль гипохлорита кальция (ДСГК)», производимая ОАО «Каустик» (Россия, республика Башкортостан, г. Стерлитамак) по ТУ9392-231-00203312-2002. Это сухой порошок,

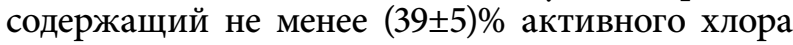

\footnotetext{
${ }^{1}$ Национальный справочно-аналитический портал о дезсредствах, зарегистрированных на территории РФ (Official information site on disinfectants). URL: http://www.dezreestr.ru (дата обращения: 30.01.2018).

${ }^{2}$ ФБУН НИИДезинфектологии. Об институте. URL: http://www.niid.ru/about/ (дата обращения: 10.04.2018).
} 
Use of Disinfectants, Registered in Russia, by the NBC Protection Troops...

Таблица 3 - Результаты экспериментальной оценки спороцидной активности растворов дезинфекционных средств на основе катионных поверхностно-активных веществ, рекомендованных производителем для стерилизации медицинских изделий

\begin{tabular}{|c|c|c|c|c|c|}
\hline \multirow[t]{2}{*}{$\begin{array}{c}\text { Коммерческое } \\
\text { название средства } \\
\text { и его состав }\end{array}$} & \multirow{2}{*}{$\begin{array}{c}\text { Концентрация } \\
\text { действующих } \\
\text { веществ в } \\
\text { рабочем } \\
\text { растворе, } \\
\text { процент }\end{array}$} & \multirow[t]{2}{*}{$\begin{array}{c}\text { Споры } \\
\text { тест-культуры }\end{array}$} & \multirow{2}{*}{$\begin{array}{c}\text { Исходная кон- } \\
\text { центрация спор } \\
\text { в растворе де- } \\
\text { зинфектанта, } \\
\text { спорхсм }^{-3}\end{array}$} & \multicolumn{2}{|c|}{$\begin{array}{c}\text { Остаточная концентрация } \\
\text { живых спор в растворе } \\
\text { дезинфектанта через... мин., } \\
\text { спорхсм-3 }\end{array}$} \\
\hline & & & & 60 & 120 \\
\hline \multirow{3}{*}{$\begin{array}{c}\text { «Дельтамин», } \\
\text { Рос-сия (50\% алкилдиме- } \\
\text { тилбензил-аммоний } \\
\text { хлорида) }\end{array}$} & \multirow{3}{*}{2,5} & $\begin{array}{l}\text { B. anthracis } \\
\text { (шт. СТИ-1) }\end{array}$ & $(1,49 \pm 0,26) \times 10^{8}$ & $(1,39 \pm 0,05) \times 10^{8}$ & $(1,42 \pm 0,11) \times 10^{8}$ \\
\hline & & $\begin{array}{l}\text { B. subtilis } \\
\text { (யт. 3) }\end{array}$ & $(1,09 \pm 0,22) \times 10^{8}$ & $(1,09 \pm 0,16) \times 10^{8}$ & $(1,04 \pm 0,05) \times 10^{8}$ \\
\hline & & B. cereus (шт. 96) & $(1,13 \pm 0,06) \times 10^{8}$ & $(1,08 \pm 0,1) \times 10^{8}$ & $(1,0 \pm 0,05) \times 10^{8}$ \\
\hline \multirow{4}{*}{$\begin{array}{c}\text { «Арквад МСВ-50», } \\
\text { Голландия } \\
\text { (50\% алкилдиметилбен- } \\
\text { зил-аммоний хлорида) }\end{array}$} & 5,0 & $\begin{array}{l}\text { B. anthracis } \\
\text { (шт. СТИ-1) }\end{array}$ & $(3,4 \pm 0,3) \times 10^{8}$ & $(2,8 \pm 0,3) \times 10^{8}$ & $(2,3 \pm 0,3) \times 10^{8}$ \\
\hline & \multirow{3}{*}{3,0} & $\begin{array}{l}\text { B. anthracis } \\
\text { (шт. СТИ-1) }\end{array}$ & $(3,4 \pm 0,3) \times 10^{8}$ & $(3,3 \pm 0,3) \times 10^{8}$ & $(3,2 \pm 0,1) \times 10^{8}$ \\
\hline & & B. subtilis (шт. 3) & $(1,7 \pm 0,2) \times 10^{8}$ & $(1,6 \pm 0,2) \times 10^{8}$ & $(4,5 \pm 0,2) \times 10^{7}$ \\
\hline & & $\begin{array}{l}\text { B. cereus (шт. 96) из } \\
\text { музея НИИД }\end{array}$ & $(3,2 \pm 0,2) \times 10^{8}$ & $(3,0 \pm 0,1) \times 10^{8}$ & $(1,3 \pm 0,1) \times 10^{8}$ \\
\hline \begin{tabular}{|c|} 
«Эмиталь-Комплит», \\
Россия \\
(20\% пероксида \\
водорода; \\
15\% алкилдиме- \\
тилбензил-аммоний \\
хлорида; \\
5\% полигекса- \\
метиленгид-рохлорида)
\end{tabular} & $\begin{array}{l}0,6 \\
0,45 \\
0,15\end{array}$ & $\begin{array}{l}\text { B. anthracis } \\
\text { (шт. СТИ-1) }\end{array}$ & $(1,1 \pm 0,02) \times 10^{5}$ & $(0,9 \pm 0,01) \times 10^{5}$ & $\begin{array}{c}\text { Не } \\
\text { исследовалось }\end{array}$ \\
\hline
\end{tabular}

(АХ) и расфасованный в металлические барабаны по 66 кг. В разных регионах посреднические оптово-торговые фирмы предлагают его по цене от 39 до 42 руб. за 1 кг.

Другим препаратом является «Гипохлорит кальция (нейтральный)», производимый кампанией «Усолье Химпром» по ТУ9392-103-576844552001. Продается в виде сухого порошка или гранул, содержит от 45 до 54\% АХ и расфасован в металлические барабаны по 50 кг. Средняя стоимость на рынке данного препарата в виде гранул составляет 60 руб. за 1 кг [19].

Среди хлорсодержащих средств в качестве нетабельных могут рассматриваться дезинфицирующие средства на основе гипохлорита натрия (натриевой соли хлорноватистой кислоты), а также средства на основе натриевой соли дихлоруксусной или трихлоруксусной кислоты.

Гипохлорит натрия в виде марки А (19\% AX) и марки Б $(17 \% \mathrm{AX})$ в России производят в соответствии с ГОСТ 11086-76 ряд коммерческих предприятий: ОАО «Каустик» (г. Стерлитамак), ООО «Новомосковский хлор» (г. Новомосковск), ООО
«Сода Хлорат» (г. Березники), ООО «Русхимтрейд» (г. Дзержинск Нижегородской области).

Девять зарегистрированных дезинфицирующих средств на основе гипохлорита натрия представляют собой жидкие концентраты, разлагающиеся при хранении с резким снижением дезинфицирующей активности. Они содержат всего от 2,5 до 4\% активного хлора, но предлагаются по цене от 90 до 140 руб. за 1 л$^{4}$. Необходимость вынужденного их использования войсками РХБ защиты для обеззараживания объектов в отношении вегетативных видов и форм опасных и особо опасных возбудителей, на наш взгляд, маловероятна и нецелесообразна. Нормируемые запасы табельных дезинфицирующих средств на основе более дешевого гипохлорита кальция в войсках РХБ защиты позволяют, с учетом небольших концентраций действующих веществ в рабочих растворах, выполнять большой объем дезинфекционных работ в отношении таких возбудителей.

Наиболее представительной группой хлорсодержащих дезинфицирующих средств явля-

\footnotetext{
${ }^{3}$ Национальный справочно-аналитический портал...

${ }^{4}$ Там же.
} 
ются, как видно из таблицы 2, средства на основе дихлор- и трихлоризоциануровой кислоты (78 зарегистрированных средств), причем 71 препарат - это дезинфектанты на основе натриевой соли дихлоризоциануровой кислоты (НДХЦК).

От средств на основе гипохлорита кальция их отличает более высокая дезинфицирующая активность в отношении всех видов и форм микроорганизмов, более низкая токсичность и коррозионная активность, хорошая растворимость без образования осадка [18-22]. В этих средствах может содержаться 45-50\% АХ. Они выпускаются в виде гранул и таблеток. Подавляющее количество этих средств, зарегистрированных для применения в России, представляют собой однотипные по составу средства в виде таблеток в герметичной пластиковой емкости. Вес таблетки может составлять от 3,2 до 3,6 г. При ее растворении выделяется 1,5 г АХ (т.е. при растворении 1 таблетки в 1 литре воды образуется дезинфицирующий раствор в концентрации $0,15 \% \mathrm{AX}$ ).

Следует отметить, что это единственная группа дезинфицирующих средств, в которой в инструкциях по применению рекомендуются объективные режимы. В частности, для дезинфекции объектов в отношении бактерий и вирусов класса низкой устойчивости к дезинфектантам (к ним относятся бактерии и вирусы, являющиеся возбудителями опасных и особо опасных инфекций) рекомендуется использовать 0,015-0,02\% по АХ раствор, при его расходе (150200) мл/м ${ }^{2}$ и экспозиции 60 мин $[11,12,22]$.

Несмотря на то, что НДХЦК является действующим веществом, обладающим спороцидной активностью, почти все зарегистрированные дезинфицирующие средства режимов применения в отношении спор не имеют. Их отработка просто не заказывалась производителем по причинам чисто коммерческого плана.

Исследованиями, проведенными в НИЦ ФГБУ 48 ЦНИИ МО РФ (г. Екатеринбург), показано, что 1,5\% по АХ раствор НДХЦК, содержащий $0,3 \%$ поверхностно-активного вещества СФ-2У, при обработке им объектов методом орошения мелкодисперсным аэрозолем с расходом 0,2 л/м² и экспозиции 60 мин эффективно обеспечивает гибель спор тест-культур $B$. anthracis (штамм СТИ-1) и B. subtilis (штамм 3) на поверхности объектов.

Анализ информации по этим средствам на сайте «ДЕЗРЕЕСТР» ${ }^{5}$ показывает, что средняя рыночная стоимость 1 кг (330 таблеток по 3,4 г) средств на основе НДХЦК составляет 366 руб. То есть стоимость 1 л такого раствора составляет порядка 11 руб. При расходе его 0,2 л/м² затраты по средству на дезинфекцию $1 \mathrm{~m}^{2}$ поверхности объекта будут составлять 2,2 руб.
Аналогичные расчеты по средству на основе гипохлорита кальция показывают, что если исходить из самой низкой цены (52 руб. за 1 кг) на препарат ДСГК с концентрацией (37-39)\% активного хлора, производимый ЗАО «Каустик» [12], и норме расхода 4,0 л/ $\mathbf{M}^{2}$, то затраты на средство для дезинфекции $1 \mathrm{~m}^{2}$ поверхности объекта в отношении споровых форм микробов составят порядка 14,8 руб. (т.е. практически в 7 раз больше, чем при использовании НДХЦК).

Однако экспериментальные исследования, проведенные в НИЦ ФГБУ 48 ЦНИИ МО РФ, показали, что использование 2,5\% (по АХ) раствора гипохлорита кальция с добавлением в раствор 0,3\% поверхностно-активного вещества СФ-2У позволяет сократить расход рабочего раствора до 0,5 л/м². В этом случае затраты по дезинфицирующему средству на обработку $1 \mathrm{~m}^{2}$ поверхности объекта будут составлять всего 1,85 руб. То есть затраты на проведение дезинфекции объектов с использованием средств на основе гипохлорита кальция и натриевой соли дихлор- или трихлоризоциануровой кислоты становятся практически сопоставимы.

Таким образом, дезинфицирующие средства на основе солей ди- и трихлоруксусной кислоты, зарегистрированные в России и имеющие рыночную стоимость до 370 руб. за 1 кг, могут при необходимости быть использованы войсками РХБ защиты в качестве нетабельных средств дезинфекции.

К высокоэффективным (в том числе и в отношении споровых форм микроорганизмов) дезинфектантам, широко используемым в медицинской практике для дезинфекции и стерилизации различных объектов, относится перекись водорода $[1,2,7,8,17,22-24]$.

Сегодня ДС на основе перекиси водорода (ПВ) представляют достаточно болышую группу (порядка 100 препаратов) зарегистрированных средств. Кислородсодержащие препараты различаются как по составу компонентов, так и по концентрации в них ПВ и, следовательно - по спектру антимикробного действия. Например, достаточно большую группу (34 дезинфицирующих средства) сегодня представляют композиции ПВ с ЧАС или с полигуанидином. Но такие средства, как правило, рекомендуются только для дезинфекции в отношении бактерий, вирусов и грибов. При этом их стоимость может до 10 раз быть выше 30\% ПВ. Поэтому в качестве нетабельных дезинфицирующих средств их рассматривать нет оснований.

Учитывая, что выраженную спороцидную эффективность растворы перекиси водорода проявляют в концентрации $(6-10) \%[2,5,17,22$, 24], то и перспективу для использования (при

${ }^{5}$ Национальный справочно-аналитический портал... 
необходимости) войсками РХБ защиты в качестве нетабельных дезинфицирующих средств могут составлять дезинфектанты, содержащие в составе не менее 10\% ПВ. Однако из 20 зарегистрированных дезинфицирующих средств, содержащих только ПВ и анионактивный или неионогенный ПАВ, таких всего $5^{6}$. В этой связи большую перспективу использования в качестве нетабельного дезинфицирующего средства представляет сама ПВ, промышленно выпускаемая в России и широко используемая медицинскими организациями на всей ее территории.

Например, помимо крупнотоннажного производства перекиси водорода с концентрацией $35-50 \%$ в г. Новочебоксарске (ОАО «Химпром») и г. Дзержинске Нижегородской области (ООО «СИНТЕЗ Ацетон»), в небольших объемах (от 15 до 150 т) такая перекись водорода производится в г. Твери («Тверская фармацевтическая кампания») и в г. Новосибирске (ООО «Аназит»). Выпускаемая этими производителями ПВ предлагается (чаще в пластиковых емкостях по 20 л) различными посредническими фирмами во многих регионах РФ.

Цена перекиси водорода составляет от 20 до 42 руб. за 1 кг в пересчете на 30\% концентрацию (цена существенно зависит от затрат на доставку товара от производителя до потребителя). Например, цена ПВ, которая производится в ОАО «Химпром», составляет от 25 руб. за 1 кг. Используя ее, можно из 1 л ПВ приготовить 3 л $10 \%$ раствора, обеспечивающего эффективное обеззараживание объекта за 60 мин при расходе 0,2 л/м ${ }^{2}$ в отношении споровых форм бактерий. При такой цене затраты на перекись водорода для эффективной обработки $1 \mathrm{M}^{2}$ поверхности ВВТ в отношении спор при положительной температуре будут составлять порядка 1,7 руб. Это сопоставимо с затратами при использовании хлорсодержащих средств по существующим режимам специальной обработки.

Как видно из таблицы 2, среди кислородсодержащих дезинфицирующих средств достаточно болышую группу представляют рецептуры, в которых основную роль действующих веществ выполняет не ПВ, а органическая надкислота. Ранее в медицинской и ветеринарной практике для дезинфекции и стерилизации различных объектов такие средства широко производились и использовались $[2,5,17,24]$. В большом объеме промышленным способом было организовано производство (например, в г. Дзержинске Нижегородской области) дезинфицирующего средства под названием «Дезоксон-4», которое представляло собой смесь, содержащую от 5 до 9\% надуксусной кислоты (НУК), от 12 до 22\% ПВ и до

\footnotetext{
${ }^{6}$ Национальный справочно-аналитический портал...

7 Там же.
}

$12 \%$ уксусной кислоты (УК). Для дезинфекции поверхностей различных объектов в отношении спор возбудителя сибирской язвы рекомендовалось его использовать в виде $1 \%$ (по НУК) раствора с расходом 0,5 л/м $\mathbf{M}^{2}$ способом орошения или 0,2 л/м² способом протирания и при экспозиции 60 мин. Для дезинфекции в отношении бактерий и вирусов, в том числе и наиболее устойчивых (типа вируса полиомиелита), их применяют в концентрации 0,05-0,2)\% (по НУК) и при экспозиции 30 мин $[2,5,17,21]$.

Как видно из таблицы 2, на рынке дезинфектантов в России предлагается (в основном для стерилизации и дезинфекции высокого уровня) более 30 подобных дезинфицирующих средств. Они представляют собой как готовые к применению растворы с содержанием от 0,14 до 0,23\% НУК и от 6 до 7,5\% ПВ, так и концентраты, содержащие до 25\% ПВ и не менее 5\% НУК. Пятнадцать дезинфицирующих средств на основе НУК предлагаются отечественными фирмами. Однако реально - это дезинфицирующие средства, производимые путем разведения готовой импортной субстанции-концентрата, с высоким содержанием НУК, ПВ и УК. В них могут присутствовать (в разном соотношении) и другие вещества в виде вспомогательных компонентов, снижающих коррозионное воздействие НУК или повышающих поверхностно-активные свойства рабочих растворов ${ }^{7}$.

Как и дезинфицирующие средства на основе НДХЦК, для дезинфекции поверхностей различных объектов в отношении спор возбудителя сибирской язвы (особенно применительно к условиям дезинфекции в очаге биологического заражения) эти средства реально не испытывались и режимов применения не имеют. Поэтому наибольшую перспективу использования для рассматриваемых целей имеют, на наш взгляд, зарегистрированные дезинфицирующие средства, представляющие собой жидкий концентрат, содержащий до 25\% ПВ и не менее 5\% НУК (их можно рассматривать аналогами проверенного отечественной практикой средства «Дезоксон-4») стоимостью от 167 до 427 руб. за литр. Рекомендуемая концентрация рабочего раствора в отношении спор возбудителя сибирской язвы составляет $1 \%$ по НУК. При использовании раствора в такой концентрации и с расходом 0,2 л/м² затраты по средству на дезинфекцию $1 \mathrm{~m}^{2}$ поверхности объекта способом орошения мелкодисперсным аэрозолем будут составлять от 6,7 до 22 руб.

Таким образом, на основании и с учетом изложенного выше, можно сделать следующие выводы:

1. Среди предлагаемых отечественными производителями зарегистрированных дезин- 
фицирующих средств наиболее пригодными для использования войсками РХБ защиты в качестве нетабельных являются средства в виде быстрорастворимых таблеток на основе НДХЦК, а также в виде жидких концентратов на основе ПВ или композиции на основе ПВ и НУК.

2. При необходимости эти дезинфицирующие средства могут эффективно и с приемле- мыми экономическими затратами быть использованы войсками РХБ защиты для проведения дезинфекционных мероприятий в отношении вегетативных и споровых форм микроорганизмов при положительных и отрицательных температурах при ликвидации эпидемических очагов искусственного и естественного происхождения.

\section{Информация о конфликте интересов}

Авторы заявляют, что исследования проводились при отсутствии любых коммерческих или финансовых отношений, которые могли бы быть истолкованы как потенциальный конфликт интересов.

\section{Сведения о рецензировании}

Статья прошла открытое рецензирование двумя рецензентами, специалистами в данной области. Рецензии находятся в редакции журнала.

\section{Список источников}

1. Буянов В.В., Никольская В.П., Канищев В.В. и др. Средства дезинфекции для ликвидации последствий биологического заражения при различных температурах окружающей среды М.: Черноголовка, 2003. 277 c.

2. Канищев В.В., Буянов В.В., Литусов Н.В., Никольская В.П. и др. Спороцидная активность дезинфицирующих средств на основе пероксида водорода // Вестник Российской академии медицинских наук. 2004. № 1. С.23-30.

3. Федеральные клинические рекомендации по выбору химических средств дезинфекции и стерилизации для использования в медицинских организациях (утверждены Профильной комиссией Минздрава России по эпидемиологии 20.11.2014 г.). М.: НП «НАСКИ», 2015. 67 с.

4. Украинцев А.Д., Власов И.Г., Крашенинникова Т.К. , Краснопевцева И.В. и др. Сравнительный анализ средств, применяемых для дезинфекции опасных микроорганизмов // Химическая и биологическая безопасность. 2005. № 6. С. 3-25.

5. Федорова Л.С., Арефьева Л.И., Путинцева Л.С. и др. Современные средства дезинфекции и дезинсекции. Характеристика, назначение, перспективы. М.: 1991. 92 с.

6. Абрамова И.М., Сукиасян А.Н., Копылова А.И. Спороцидная активность глутарового альдегида в зависимости от $\mathrm{pH}$ и температуры растворов // Ocновные направления дезинфекционного дела. Сборник научных трудов. М.: 1986. С. 58-61.

7. Шандала М.Г. Актуальные вопросы общей дезинфектологии. Избранные лекции. М.: 2009. 111 с.

8. Райнбабен Ф. Основы противовирусной дезинфекции. М.: 2014. 525 с.

9. Абрамова И.М. Изучение спороцидной ак- тивности глутарового альдегида и композиций на его основе // Основные направления дезинфекционного дела: сборник научных трудов. М., 1981. С. 46-48.

10. Дезинфекционные средства. Справочник в двух томах, выпуск 3-й. Дезинфицирующие средства. Т. 1, часть 1 / Под ред. Иванова С.И. и Шандалы М.Г. M.: 2000. 207 c.

11. Канищев В.В., Еремеева Н.И. Выбор и применение современных дезинфицирующих средств. Желаемое и реальность // Дезинфекционное дело. 2016. № 1 . С. 28-36.

12. Шеина И.В., Скворцова Е.К., Тибаева В.Н. Эффективность водных растворов катионных веществ при обеззараживании поверхностей // Научные основы дезинфекции и стерилизации: сборник научных трудов. М.: 1980. С. 16-19.

13. Нехорошева А.Г., Скворцова Е.К., Лиманов B.Е. и др. Изучение антибактериальной активности алкилдиметилбензиламмоний хлорида // Проблемы дезинфекции и стерилизации: труды Центрального научно-исследовательского института дезинфектологии. М., 1969, Вып. 20. С. 40-49.

14. Федорова .С.Л, Арефьева Л.И., Панкратова Г.П. и др. Антимикробная активность, дезинфицирующие свойства и токсичность алкил (C12-C14) диметилбензиламмоний хлорида // Современные методы и средства дезинфекции и стерилизации. М.: 1989. С. $17-20$.

15. Гембицкий П.А, Воинцева И.И. Полимерный биоцидный препарат полигексаметиленгуанидин. Запорожье, 1998.43 с.

16. Шестопалов Н.В., Федорова Л.С., Серов А.А. Научно-методическое обоснование ротации дезинфицирующих средств в медицинских организациях на основе оценки чувствительности к ним госпиталь- 
ных штаммов микроорганизмов // Дезинфекционное дело. 2017. № 4. С. 28-32.

17. Федорова Л.С. Теория и практика совершенствования дезинфицирующих средств. М.: 2006. 216 с.

18. Барсукова Э.М., Рубинов Г.Е., Соколова Н.Ф. Эффективность хлорцина, ДП- 2, дезоксона при обеззараживании объектов, зараженных возбудителем сибирской язвы // Актуальные вопросы дезинфекции и стерилизации. М. 1984. С. 14-17.

19. Обзор рынка гипохлорита кальция в СНГ. М.: 2010. 92 c.

20. Соколова Н.Ф., Михайлова Л.М. Оптимальный способ активации натриевой соли дихлоризциануровой кислоты // Основные направления развития науки и практики дезинфекционного дела. М., 1981. С. 26-29.

21. Соколова Н.Ф. Актуальные проблемы не- специфической профилактики сибирской язвы // Материалы научно-практической конференции, посвященной 75-й годовщине со дня рождения Заслуженного деятеля науки Российской Федерации академика РАМН Беньямина Лазаревича Черкасского. М., 2009. C. 59-68.

22. Jto K.A., Denny C.B., Brawn Ch.K., Voo M., Seeger M. Resistance of bacterial spores to hydrogen peroxide // Food Technol. 1973. V. 27. P. 58-66.

23. Sprobig M. Peressigsaure-25 Jahre Entwieckliend und Erfarung. Mixrobielle UmwieltundantimicrobielleMabhahmen // Schritenreiche fur Teorie und Praxis in Medizin, Pharmazie und Wirtckhaft. Leipzig. 1988. V. II. P. 136-139.

24. Baaldry M.L. The bactericidal, fungicidal and sporicidal properties of hydrogen peroxide and peracetic acid // Appl. Bact., 1983. V. 54, № 3. P. 417-423.

\title{
Об авторах
}

Филиал федерального государственного бюджетного учреждения «48 Центральный научно-исследовательский институт» Министерства обороны Российской Федерации (г. Екатеринбург). 620085, Российская Федерация, г. Екатеринбург, ул. Военная, д. 1.

Канищев Владимир Васильевич. Старший научный сотрудник отдела, д-р мед. наук, проф.

Морозов Александр Сергеевич. Начальник отдела, канд. техн. наук.

Лакомов Владимир Павлович. Ведущий научный сотрудник, канд. техн. наук.

Омельяненко Юлия Валерьевна. Старший научный сотрудник отдела, канд. техн. наук.

Бухаева Светлана Рамазановна. Научный сотрудник отдела.

Трочев Роман Геннадвевич. Старший научный сотрудник отдела.

Муравьев Алексей Геннадвевич. Старший научный сотрудник отдела.

Контактная информация для всехавторов: 27nc_1@mil.ru Контактное лицо: Канищев Владимир Васильевич; 27nc_1@mil.ru

\section{USE OF DISINFECTANTS, REGISTERED IN RUSSIA, BY THE NBC PROTECTION TROOPS IN BIOLOGICAL EMERGENCIES}

\author{
V.V. Kanischev, A.S. Morozov, V.P. Lakomov, Yu.V. Omelyanenko,
}

S.R. Buhaeva, R.G. Troshev, A.G. Muravyov

\begin{abstract}
Branch Office of the Federal State Budgetary Establishment "48 Central Scientific Research Institute» of the Ministry of Defence of the Russian Federation, Zvezdnaya street 1 , Yekaterinburg 620085, Russian Federation
\end{abstract}

\begin{abstract}
Disinfection measures in the event of an outbreak of epidemics created by natural and artificial causes are connected with high consumption of disinfectants, especially in anthrax foci. This does not exclude the situation, when the stock of authorized disinfectants may turn out to be insufficient. So it will be necessary to use non-authorized disinfectants. The aim of this paper is to reveal among the disinfectants, registered in Russia, the most convenient to use by the NBC Protection Troops in epidemic emergencies. 770 such disinfectants have been analyzed. It is established, that the disinfectants of the group of cationic surfactants (CPAS) based on quaternary ammonium compounds,
\end{abstract}


amines, polyguanidines and compositions of these active substances in various combinations have been introduced into practice of Russian medical institutions for almost two decades. The analysis of the scientific literature and the results of our own experiments show that the solutions of these disinfectants, recommended for high-level sterilization and disinfection of medical devices, do not have any sporicidal effect. Because of that, only disinfectants based on chlorine-containing and oxygen-containing active substances can be interesting for the NBC Protection Troops and may be used as non-authorized disinfectants. The solutions of such agents have a wide range of antimicrobial action and provide complete death of not only bacteria, viruses and fungi, but also spores of various bacilli, at temperatures below $0^{\circ} \mathrm{C}$ as well. The most convenient in use by the NBC Protection Troops are the products in the form of instant tablets based on sodium dichloroisocyanuric acid, as well as in the form of liquid concentrates based on hydrogen peroxide or peracetic acid. Because of that the above mentioned agents should be used by the NBC Protection Troops in cases of biological emergencies according to the regimes of standard approved disinfectants.

Keywords: disinfection; dichloroisocyanuric acid; peracetic acid; focus of biological contamination; hydrogen peroxide; anthrax; sporicidal disinfecting agent; approved means of disinfection; technical means of special decontamination; quaternary ammonium compound; epidemic emergency.

For citation: Kanischev V.V., Morozov A.S., Lakomov V.P., Omelyanenko Yu.V., Buhaeva S.R., Troshev R.G., Muravyov A.G. Use of Disinfectants, Registered in Russia, by the NBC Protection Troops in Biological Emergencies // Journal of NBC Protection Corps. 2018. V. 2 № 4. P. 57-67.

\section{Conflict of interest statement}

The authors declare that the research was conducted in the absence of any commercial or financial relationship that could be construed as a potential conflict of interest.

Peer review information

The article has been peer reviewed by two experts in the respective field. Peer reviews are available from the Editorial Board.

\section{References}

1. Buyanov V.V., Nikolskaya V.P., Kanischev V.V. at al. Disinfectants for the liquidation of aftereffects of biological contamination in different thermal conditions of the environment // Institute of Problems of Chemical Physics RAS, Chernogolovka, 2003. 277 p. (in Russian).

2. Kanischev V.V., Buyanov V.V. Litusov N.V., Nikolskaya V.P. at al. Sporicidial activity of disinfectants on the base of hydrogen peroxide // Annals of the Russian academy of medical sciences. 2004. № 1. P. 23-30 (in Russian).

3. Federal clinic recommendations for the choice of chemical disinfectants and means of sterilization for usage in medical organizations (adopted by the Profile commission of Health Ministry on epidemiology 20.11.2014). M.: 2015. 67 p. (in Russian).

4. Ukraintsev A.D., Vlasov I.G., Krasheninnikova T.K. et al. Comparative analysis of means used for disinfection of dangerous microorganisms // Chemical and biological safety. 2005. № 6. P. 3-25 (in Russian).

5. Fedorova L.S., Arefieva L.I., Putintseva L.S. at al. Modern means of disinfection and disinsection. Characteristics, appointment, prospects. M.: 1991.92 p. (in Russian).
6. Abramova I.M., Sukiasyan A.N., Kopylova A.I. Sporicidial activity of glutaraldehyde in accordance to $\mathrm{pH}$ and temperature solutions // Basic directions of disinfection. Collection of scientific works. M., 1986. P. 58-61 (in Russian).

7. Shandala M.G. Topical issues of common disinfectology. Selected lectures. M.: Medecine, 2009. 111 p. (in Russian).

8. Rheinbaben Friedrich von. Principles of virucidal disinfection. M.: 2014. 525 p. (in Russian).

9. Abramova I.M. Study of sporicidial activity of glutaraldehyde and the compositions on its base // Main Trends of Disinfection. Collection of scientific works. M., 1981. P. 46-48 (in Russian).

10. Disinfectants. Handbook in two volumes. Is. 3. Disinfectants. Part 1, V. 1 / Ed. S.I. Ivanov and M.G. Shandala. M.: 2000. 207 p. (in Russian).

11. Kanichev V.V., Eremeeva N.I. Choice and use of current disinfectants. Desired and reality // Disinfection affairs. 2016. № 1. P. 28-36 (in Russian).

12. Sheina I.V., Skvortsova E.K., Tibaeva V.N. at al. The effectiveness of aqueous solutions of cation-carrier substances during the disinfection of surfaces // Scientific 
bases of disinfection and sterilization. Scientific works. The analects. M.: 1980. P. 16-19 (in Russian).

13. Nehorosheva A.G., Skvortsova E.K., Limanov V.E. at al. Study of antibacterial activity of alkyldimethylbenzylammonium chloride. Problems of disinfection and sterilization // Works of Central Scientific Research Institute of Disinfection. Moscow, 1969. Ed. 20. P. 40-49 (in Russian).

14. Fyodorova S.L., Arefieva L.I., Pankratova G.P. at al. Antimicrobial activity, disinfectant qualities and toxicity of alkyl (P. 12-14) dimethylbenzilammonium chloride // The contemporary methods and means of disinfection and sterilization. M.: 1989. P. 17-20 (in Russian).

15. Gembizkiy P.A., Voinzeva I.I. Polymer biocide preparation polyhexamethylene guanidine. Zaporozhie. 1998, 43 p. (in Russian).

16. Shestopalov N.V., Fyodorova L.S., Serov A.A. Scientific-methodic substantiation of rotation of disinfectants in medical organizations on the bases of the estimation to sensibility to hospital strains of microorganisms // Disinfection affairs. 2017. № 4. P. 28-32 (in Russian).

17. Fyodorova L.S. Theory and practice of disinfectants development. M.: 2006. 216 p. (in Russian).

18. Barsukova E.M., Rubinov G.E., Sokolova N.F. Effctivity of clorcine, DP-2, desoxone during the disifection of objects, contaminated by the pathogen of anthrax // Actual questions of disinfection and sterilization. M.: 1984. P. 14-17 (in Russian).

19. Observation of hypochlorite calcium market in CIS // M.: 2010. 92 p. (in Russian).

20. Sokolova N.F., Mihailova L.M. Optimal way of activation of sodium salt of diclorisicianurate acid // Basic directions of the development of science and practice of disinfection. M.: 1981. P. 26-29 (in Russian).

21. Sokolova N.F. Actual questions of nonspecific prevention of anthrax // Materials of scientific-practical conference dedicated to the 75-th birth anniversary of the Honored worker of science of the Russian Federation academician of RAMS Benyamin Lazarevich Cherkasskiy. M.: 2009. P. 59-68 (in Russian).

22. Jto K.A., Denny C.B., Brawn Ch.K., Voo M., Seeger M. Resistance of bacterial spores to hydrogen peroxide // Food Technol. 1973. V. 27. P. 58-66.

23. Sprobig M. Peressigsaure-25 Jahre Entwieckliend und Erfarung. Mixrobielle Umwielt und antimicrobielle Mabhahmen // Schritenreiche fur Teorie und Praxis in Medizin, Pharmazie und Wirtckhaft. Leipzig. 1988. V. II. P. 136-139.

24. Baaldry M.L. The bactericidal, fungicidal and sporicidal properties of hydrogen peroxide and peracetic acid // Appl. Bact. 1983. V. 54. № 3. P. 417-423.

\section{Authors}

Branch Office of the Federal State Budgetary Establishment « 48 Central Scientific Research Institute» of the Ministry of Defence of the Russian Federation. Zvezdnaya street 1, Yekaterinburg 620085, Russian Federation.

Kanischev Vladimir Vasilyevich. Senior Researcher of the Department. Doctor of Medical Sciences. Professor.

Morozov Aleksandr Sergeevich. Chief of the Scientific and Research Department. Candidate of Technical Sciences.

Lakomov Vladimir Pavlovich. Leading Researcher of the Department. Candidate of Technical Sciences.

Omelyanenko Yulia Valeryevna. Senior Researcher of the Department. Candidate of Technical Sciences.

Buhaeva Svetlana Ramazanovna. Researcher of the Department.

Troshev Roman Gennadyevich. Senior Researcher of the Department.

Muravyov Aleksey Gennadyevich. Senior Researcher of the Department.

Contact information for all authors: 27nc_1@mil.ru Contact person: Kanischev Vladimir Vasilievich; 27nc_1@mil.ru 